\title{
Fecal microbiota transplant by push enteroscopy to treat diarrhea caused by Clostridium difficile
}

\author{
Transplante de microbiota fecal por enteroscopia alta para o tratamento da diarreia \\ causada por Clostridium difficile
}

\author{
Arnaldo José Ganc ${ }^{1}$, Ricardo Leite Ganc², Sílvia Mansur Reimão ${ }^{3}$, Alberto Frisoli Junior ${ }^{1}$, Jacyr Pasternak ${ }^{2}$
}

\begin{abstract}
Clostridium difficile is the major etiological agent of pseudomembranous colitis and is found in up to $20 \%$ of adult inpatients. The recommended treatment is antibiotic therapy with metronidazole and/or vancomycin. However, the recurrence rate may reach up to $25 \%$ and it increases in each episode. The newest alternative to treat diarrhea due to recurrent Clostridium difficile is fecal microbiota transplantation. The procedure was performed in 12 patients, with a 6-month follow-up on 10 of them. Of the ten cases, bacterial recurrence was diagnosed in only one patient, after a course of antibiotic to treat urinary tract infection, without presenting with diarrhea. The particularity of our study, besides being an unprecedented event in South America, is the way to perform the infusion of fecal microbiota by enteroscopy.
\end{abstract}

Keywords: Clostridium difficile; Transplantation homologous; Enterocolitis, pseudomembranous/etiology; Endoscopy/methods; Diarrhea/drug therapy; Metronidazole/therapeutic use; Vancomycin/therapeutic use

\section{RESUMO}

0 Clostridium difficile é o principal agente etiológico da colite pseudomembranosa e está presente em até $20 \%$ dos adultos hospitalizados. 0 tratamento recomendado é a antibioticoterapia com metronidazol e/ou vancomicina. No entanto, a taxa de recidiva chega a $25 \%$ e aumenta conforme a recorrência. A mais recente alternativa para o tratamento da diarreia por Clostridium difficile recorrente é 0 transplante de microbiota fecal. Realizamos 12 casos, tendo 10 deles ocorridos há mais de 6 meses. Desses dez casos, houve recidiva bacteriana em apenas um deles, após novo ciclo de antibiótico para tratamento de infecção do trato urinário, sem a presença de diarreia. A particularidade da nossa casuística, além de ser um fato inédito na América do Sul, deveu-se à maneira de realizar a infusão da microbiota fecal, que foi por via enteroscópica.

Descritores: Clostridium difficile; Transplante homólogo; Enterocolite pseudomembranosa/etiologia; Endoscopia/métodos; Diarreia/quimioterapia; Metronidazol/uso terapêutico; Vancomicina/uso terapêutico

Clostridium difficile, the main etiological agent of pseudomembranous colitis, is an anaerobic, sporeforming, Gram-positive bacillus present in the intestinal flora of up to $20 \%$ of hospitalized adults. Of these patients, only 1 to $5 \%$ develop diarrhea and the rest remains asymptomatic. The risk of contracting the infection seems to be directly proportional to the length of stay, and is related to the use of antibiotics. However, the incidence, intensity and recurrence rate of this disease have been increasing. Furthermore, the introduction of the polymerase chain reaction (PCR) technique to screen for Clostridium difficile made the detection of this organism significantly more effective, which may explain the striking increase in incidence of this infection. ${ }^{(1)}$

The clinical picture resulting from this infection ranges from asymptomatic cases, to diarrhea that improves by simply discontinuing antibiotics and applying clinical support measures, or event to cases of uncontrollable diarrhea, with subsequent sepsis and toxic megacolon. The mortality rate can be as high as $58 \%$ in the latter cases. $^{(2)}$

\footnotetext{
'Universidade Federal de São Paulo, São Paulo, SP, Brazil.

${ }^{2}$ Hospital Israelita Albert Einstein, São Paulo, SP, Brazil.

${ }^{3}$ Universidade de São Paulo, São Paulo, SP, Brazil.

Corresponding author: Silvia Mansur Reimão - Avenida Albert Einstein, 627/701 - Morumbi -Zip code: 05652-900 - São Paulo, SP, Brazil - Phone: (55 11) 95282-0002 - E-mail: silvia_mansur@yahoo.com.br Received on: May 15, 2014 - Accepted on: Feb 22, 2015
}

DOI: 10.1590/S1679-45082015MD3106 
The treatment currently recommended is antibiotic therapy with metronidazole and/or vancomycin.

The response to antibiotics may be poor, and the recurrence rate can reach up to $25 \%$. After the first relapse, the risk of a second one rises to $40 \%$, and for multiple recurrences, the risk exceeds $50 \%$. $^{(3)}$ Recently, fidaxomicin emerged as an alternative for cases of resistant Clostridium difficile. Though more efficient than traditional antibiotics, this drug is not yet available in Brazil, and its efficacy has not been definitively assessed.

The most recent alternative for the treatment of diarrhea caused by recurrent Clostridium difficile is fecal microbiota transplantation.

The concept is not new and the first publications date back to $1958 .{ }^{(4)}$ However, for many reasons, either cultural or due to disbelief among the scientific community, it took more than five decades for this line of thought to be resumed. In the beginning of the decade, several articles described the use of fecal microbiota transplantation in patients with recurrent Clostridium difficile infection. However, the medical community remained incredulous. It was only last year after a publication in The New England Journal of Medicine (NEJM) - that the medical community realized how promising this technique could be. The most impressive about the article published in the NEJM was the striking difference between the groups treated with antibiotics or fecal microbiota transplantation. The latter was so superior that the study was interrupted by the Institutional Review Board of the organization. ${ }^{(3)}$

In previous publications, the infusion of fecal microbiota was performed using enemas, colonoscopies or slow infusion by nasogastric tube, with the patient awake. ${ }^{(1-4)}$

The donor is usually a family member of the patient who meets certain criteria, such as not having used antibiotics in the previous six months, being immunocompromised, and having no history of illicit drug use, tumors or inflammatory bowel disease. Some tests are performed for screening: serology for hepatitis $\mathrm{A}, \mathrm{B}$ and $\mathrm{C}$, human immunodeficiency virus (HIV), fecal parasitology, fecal test for Clostridium difficile, and fecal culture. After donor selection, the fecal material is collected and processed in the laboratory by dilution with $0.9 \%$ saline, resulting in the solution to be infused into the recipient.

We recently had the opportunity to discuss an unprecedented case of an 82-year-old patient with chronic renal failure and Clostridium difficile diarrhea for over 4 months. The patient was treated with metronidazole and vancomycin several times with numerous relapses. He was offered the option to receive a fecal microbiota transplantation. His only condition was that he did not witness the nasoenteral infusion. For this reason, we chose to perform the fecal microbiota transplantation endoscopically, under sedation, infusing the microbiota through the working channel in the proximal jejunum. The procedure was uneventful and, to our surprise, the diarrhea stopped within 24 hours.

Patient has been followed-up for about 12 months with no clinical relapse.

Since then, we have carried out another 12 cases, 10 of which over 6 months ago. In only one of these 10 cases did the bacterial infection relapse, after a new cycle of antibiotic therapy to treat an urinary tract infection, without diarrhea. In addition to its being an unprecedented case in South America, another particularity of our case series was the method for the fecal microbiota infusion.

To date, there are no reports in the literature of fecal microbiota transplantations performed by oral push enteroscopy. We believe this is a good alternative for not requiring the patient to be subjected to colonoscopy, or exposed to the physical and moral discomfort of receiving a nasoenteral infusion of fecal material.

\section{REFERENCES}

1. Kassam Z, Lee $\mathrm{CH}$, Yuan $\mathrm{Y}$, Hunt RH. Fecal microbiota transplantation for Clostridium difficile infection: systematic review and meta-analysis. Am J Gastroenterol. 2013;108(4):500-8. Review.

2. Rubin TA, Gessert CE, Aas J, Bakken JS. Fecal microbiome transplantation for recurrent Clostridium difficile infection: report on a case series. Anaerobe. 2013;19:22-6.

3. Kelly CP. Fecal microbiota transplantation--an old therapy comes of age. $\mathrm{N}$ Eng J Med. 2013;368(5):474-5.

4. Eiseman B, Silen W, Bascom GS, Kauvar AJ. Fecal enema as an adjunct in the treatment of pseudomembranous enterocolitis. Surgery. 1958;44(5):854-9. 